Louisiana State University

LSU Digital Commons

Faculty Publications

Department of Oceanography \& Coastal

Sciences

12-1999

Salinity History of Coastal Marshes Reconstructed from Diatom Remains

Michael L. Parsons

Quay Dortch

R. Eugene Turner

Nancy N. Rabalais

Follow this and additional works at: https://digitalcommons.Isu.edu/oceanography_coastal_pubs

Digitart of the Oceanography Commons

Commons

Network

Logo 


\title{
Salinity History of Coastal Marshes Reconstructed from Diatom Remains
}

\author{
Michael L. Parsons ${ }^{i}$ \\ QUAY DORTCH \\ Louisiana Universities Marine Consortizm \\ 8124 Highway 56 \\ Chauvin, Louisiana 70344 \\ R. EUGENE TURNER \\ Coastal Ecology Institute and Department of Oceanography and Coastal Sciences \\ Louisiana State University \\ Baton Rouge, Louisiana 70803
}

NANCY N. RABALAIS

Louisiana Universities Manine Consontium

8124 Highway 56

Chanvin, Louisiana 70344

\begin{abstract}
Sediment cores were collected from three Louisiana coastal marsh ponds, dated with radioisotopes, and analyzed for diatom remains to determine if long-term salinity changes were evident in the sediment record. A diatom based salinity index formulated from a statistical comparison of available salinity data and changixg diatom assemblages demonstrated that diatom remains appear to preserve salinity signals in coastal brackish and salt marsh environments. The salinity index was applied to sediment cores spanming the late 1600 s to the 1990 s and provided a more complete record of salinity than field data, which were temporally and spatially incomplete. The salinity reconstructions indicated that salinity has increased at two sites and decreased at a third since the early 1900s. The salinity changes are less than $1 \%$ per decade in all cases, and may be due to natural variability as depicted by the wide range of salinities observed. between the late $1600 \mathrm{~s}$ and 1900 . Salinity regimes may be very localized $<2 \mathrm{~km}$ from a hydrologic source), indicating single-site studies may not be applicable to regional inferences. This study demonstrates that diatoms can be used to reconstruct past salinity in coastal narsh environments and can provide a useful tool with which to study the changing hydrology of river-influenced ecosystems.
\end{abstract}

\section{Introduction}

Salinity changes resulting from hydrologic modification and habitat alteration in many coastal marshes around the world are of great concern. The modification of rivers (e.g., dams and levees; Meade and Parker 1984) and estuarine systems (e.g., dredging and impoundments; Swenson and Turner 1987; Turner 1987) have affected estuarine productivity (Glenn et al. 1996), coastal morphology (Wang 1996; Stanley and Goodfriend 1997), and freshwater resources (Baird and Heymans 1996; Wang 1996; Stanley and Coodfriend 1997). Much larger river modification projects are underway (e.g., the Three Gorges Dam System on the Changiang River; Dudgeon 1995) or are planned

\footnotetext{
1 Corresponding author; tele: $808 / 9747783$ fax: $808 / 974$ 7693; email: mparsons@hawaii.edu; Present address: Marine Science Department, University of Hawaii at Hilo, $200 \mathrm{~W}$. Kawili Street, Hilo, Hawaii 967204091 .
}

for the near future (e.g., dam construction on the Mekong River; Wolanski et al. 1996). The longterm effects of hydrologic changes are not known in most cases, although many researchers acknowledge that such studies are needed (e.g., Zedler et al. 1980). While various restoration and remediation projects are underway to counter the effects of hydrologic modifications, many of these projects cannot be adequately assessed yet (Thom 1997). Orson (1996) suggested paleoecological techniques should be applied more in the study and management of coastal marshes. The resulting data would aid in determining the degree to which the system has been modified and provide historic data from which future projections can be made.

Coastal Louisiana provides a good case study of how an ecosystem is affected by hydrologic modifications, of restoration projects underway to counter hydrologic effects, and how the lack of longterm data hinders formulation of appropriate res- 
toration efforts. Louisiana contains $41 \%$ $(10,114,000$ ha of the $25,000,000$ ha) of the coastal marshes of the continental United States (Turner and Gosselink 1975), yet accounts for $80 \%$ of recent wetland loss (i.e., erosion; Alexander et al. 1986). The high rates of wetland loss $\left(0.86 \% \mathrm{yr}^{-1}\right.$ between 1955 and 1978; Baumann and Turner 1990), coupled with the subsequent economic losses (Costanza and Farber 1985), place wetland loss issues in the forefront of scientific and political debate in Louisiana. While there is consensus that wetland loss is a natural resource management problem, the causes are imperfectly understood, making it difficult to implement adequate preventative and remedial measures to counter wetland loss.

Coastwide increases in salinity have been hypothesized and debated as one of the major factors leading to wetland loss (Madden et al. 1988; Reed 1989; Gagliano 1994; Turner 1997). Salt water may stress and kill marsh plants, especially freshwater plants. This in turn can result in land loss due to the reduced ability of the marsh plants to hold organic matter in place (Good et al. 1982; Mckee and Mendelssohn 1989). Plant presence or absence also is affected by many other, often related, factors (e.g., persistence and frequency of flooding; McKee and Mendelssohn 1989; Reed 1990; Cahoon and Reed 1995; Reed 1995). The main evidence supporting coastwide salinity increases as a factor in wetland losses is the northward movement of salt-tolerant marsh plants over the past several decades (Chabreck and Linscombe 1982; Fuller et al. 1995) and a northward extension of oyster leases in Barataria Bay (Van Sickle et al. 1976). Longterm salinity data (extending back to the mid 1950 s in some cases) from 38 stations spread over coastal Louisiana demonstrate that salinities have increased at some stations $\left(0.1 \% \mathrm{yr}^{-1}\right.$ to $2.2 \%$ $\left.\mathrm{yr}^{-1}\right)$, but decreased $\left(-0.1 \% \mathrm{yr}^{-1}\right.$ to $\left.-3.7 \% 0 \mathrm{yr}^{-1}\right)$ or remained unchanged at most (Wiseman et al. 1990; Swenson and Swarzenski 1995). These results indicate there is little evidence for a coastwide increase in salinity. The salinity increases appear to be localized events probably due to the dredging of navigation channels perpendicular to the coast (Wang 1988; Wiseman et al. 1990). Unfortunately, available salinity data are temporally and spatially sparse and are too recent to provide the baseline needed to test if, and to what extent, coastwide salinity in Louisiana has changed in this century.

One approach that can rectify this lack of data is the study of the sediment record through the analysis of diatom valves in a dated sediment core (i.e., a paleoenvironmental reconstruction). Diatoms are useful indicators of past environmental conditions because their morphology is species- specific, species have specific water quality-chemistry preferences, and the valves preserve well in sediments (Battarbee 1986). Identification and enumeration of diatom valves coupled with information on optimal water conditions for growth can be used to reconstruct salinity at the time the diatoms were living. Much work has been conducted to classify diatoms according to their salinity preferences and this work has intensified in recent years (reviewed by Juggins 1992) in response to the increased application of paleoenvironmental reconstruction studies. Sediment core dating has become much more refined in the past two decades, allowing higher resolution studies of past environmental conditions using dated sediment cores (Schelske 1991). This refinement coupled with the recent scientific and managerial desire for longterm data has resulted in the present interest in paleoenvironmental reconstructions.

Paleoenvironmental reconstructions have been used to study salinity changes in closed systems such as lakes and reservoirs. Progressive freshening of uplifted lakes and impounded estuaries in Scandinavia has been demonstrated using diatom assemblages in cores (Cleve 1899; Räsänen and Tolonen 1988; Räsänen 1986). Studies of saline lakes in the northern Great Plains region of North America have been conducted to develop and calibrate diatom-based paleosalinity models. These models have been used to determine diatom responses to various ions (Cumming and Smol 1993; Wilson et al. 1994, 1996) and to study paleoclimate changes (Cumming and Smol 1993; Fritz et al. 1998), including precipitation (Fritz 1990) and droughts (Laird et al. 1996a,b, 1998).

In coastal and estuarine environments the use of diatom remains to study salinity changes has been more qualitative. Changing diatom assemblages have been associated with coastal transgression and regression events (Cleve 1899; Denys and Verbruggen 1989; Vos and de Wolf 1993; Espinosa 1994) and increased freshwater inputs to estuaries (Cooper 1995). Diatoms as quantitative indicators of changing salinity in recent sediments of estuarinemarsh systems have had limited use, unlike the case in lakes and reservoirs. One of the few examples of such a study is that by Juggins (1992), who developed a salinity transfer function along a salinity gradient in the Thames estuary and used this model to reconstruct salinities at sites around London, England.

Estuarine (and coastal marsh) salinity reconstructions have not been utilized extensively, possibly due to the dynamic changes typical of these environments. Spatial studies conducted on the living diatom assemblages found in estuarine and coastal marsh environments have demonstrated 


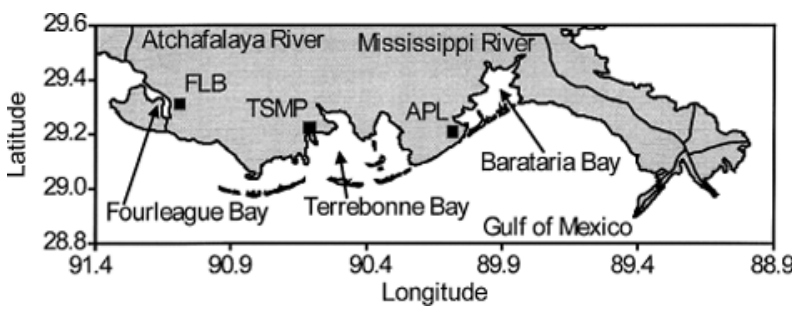

Fig. 1. A map of central coastal Louisiana showing the locations of the three study sites: the Fourleagide Eay brackish marsh pond (EID), the Terebonne Bay arit marsh pond (TSML), and Airolane Lake (API.). Iroportant geographical features are labeled. Salinity monitoring stations wirere located either git the same site (e.g. APL) or within $2 \mathrm{kn}$ ( $F \mathrm{LB}$ and TSMT') of the coring sives, and are therefore not marked.

that diatom assemblages show patterns of zonation regardless of the highly variable nature of these systems. Several studies have been conducted to determine how diatom assemblages change along a salinity gradient in estuaries and salt marshes (McIntire and Overton 1971; Moore and McIntire 1977; Amspoker and McIntire 1978; Admiraal and Peletier 1980; Cook and Whipple 1982; Wildermann 1987; Juggins 1992; Underwood et al. 1998). These studies demonstrated that diatom assemblages shifted dramatically from a freshwater population to an estuarine population at a salinity threshold from as low as $1 \%$ (Mclntive and $O \mathrm{w}$ erton 1971) to as bigh as 7\%o (Admiraal and Peletier 1980). Because many diatom species have specific salinity preferences at higher salinities (e.g., Juggins 1992; Underwood et al. 1998) they should be usetul as a proxy for past salinity changes in coastal environments.

While diatoms have been used successfully to document bistorical salinity changes in closed systems such as lakes and reserwirs, they have been used less frequently in estuarine systems, possibly due to the highly variable nature of this environment. The living diatom flora of estuarine environments exhibit quantifable changes along salinity gradients, and many estuarine systems altered by hydrologic modifications may have these effects quantified and therefore better understood through salinity reconstruction studies. The goals of this study were to determine if diatom remains preserved a salinity signal in the coastal marsh sediments of Lowisiana, and, if so, to use diatom remains to reconstruct salinity changes in the past.

\section{Materials and Methods \\ CORE COLIECTION}

We sampled three marsh water bodies in the south ${ }^{\circ}$ entral region of coastal Louisiana (Fig. 1): east of Fourleague Bay (FLB), northwest of Terre bomne Bay (TSMP), and west of Barataria Bay (Air- plane Lake-APL). Two sediment cores were collected manually at each of the three sites in August 1992 (TSMP), August 1993 (APL), and October 1994 (FLB). All cores were collected in a plastic tube ( 3 inch diam, $1.3 \mathrm{~m}$ long). Using $\sim 1 \mathrm{~m}$ tubes to collect cores underwater in $a-1 \mathrm{~m}$ deep salt marsh pond made accurate measurement of compaction during core collection impossible, so we measured compaction during extrusion in the laboratory. Cores were stored at $4 \mathrm{C}$. The longest core was split the day after collection on a custom-made threaded extruder, allowing precise measurements for shicing. Visual observations and core length were recorded prior to and during extrusion. Each of the cores was split into 1 -cm increments, which wexe then homogenized and subsampled.

\section{Coke Datidic}

Selected samples were dated by ${ }^{\text {is? }} \mathrm{Cs}$ (Milan et al. 1995) and ${ }^{210} \mathrm{~Pb}$ (Cutshall et al. 1983) using a Princeton GammaTech $60 \mathrm{~mm}$ diam intrinsic germanium "N" type coaxial detector ( $40 \%$ efficien" cy) interfaced to an EG\&G Ortec $92 \mathrm{X}$ spectrum master integrated gamma-spectroscopy system. Samples for ${ }^{2} \mathrm{~Pb}$ were held for 2 wh before analysis to allow for equilibrium between atmospheric

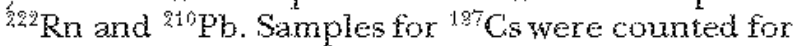
at least $4 \mathrm{~h}$ in order to yield a counting error of $10 \%$ in the vicinity of $1963-1964$, the year of peak ${ }^{187}$ Cis fallout for the southeastern U.S. (Pennington et al. 1973). Samples for $210 \mathrm{~Pb}$ were briefly counted with a source of "i $\mathrm{Pb}$ to measure the sample selfabsorption potential. The samples were then recounted for $24 \mathrm{~h}$ in order to obtain a significant amount of net counts above background. To determine supported $20 \mathrm{~Pb}$, additional counts were conducted for $214 \mathrm{~Pb}$ activity. Supported "pb was subtracted from the total to obtain excess $210 \mathrm{pb}$, from which sedimentation rates were determined. Results for ${ }^{197} \mathrm{G}$ and $210 \mathrm{~Pb}$ are reported as $\mathrm{pti} \mathrm{g}^{-1}$ (dry wt sediment).

The ${ }^{137} \mathrm{C}$ - $\mathrm{s}$-based sedimentation rates were deter mined as follows: the difference beween the date each core was collected and 1963-1964 was divided by the depth where the peak in ${ }^{197} \mathrm{Cs}$ activity oc curred. Sedimentation rates were determined from the excess ${ }^{210} \mathrm{~Pb}$ using the constant rate of supply (CRS) model. The assumption was made that there is negligible migration of ${ }^{210} \mathrm{~Pb}$ in the sediment and that the supply of excess ${ }^{210} \mathrm{~Pb}$ is con stant over time. Sedimentation rates were determined through the inverse of the slope of the least squares regression line that was fited to each ${ }^{210} \mathrm{~Pb}$ profile. The ${ }^{127} \mathrm{Cs}$ and ${ }^{210} \mathrm{~Pb}$ estimated sedimenta tion rates were averaged to give an overall sedimentation rate that would apply for the whole length of each sediment core. 


\section{DIATOM ANALXSIS}

Separate portions of selected homogenized samples were prepared and analyzed for diatoms according to Parsons (1998). Glass microspheres (20um diam, Unisciences, Ltd.) were added to the sample (to estimate absolute abundance of diatoms: Battarbee and Kneen 1982) in a 15-ml graduated polypropylene centrifuge tube; clay particles were removed by rinsing several times with $2 \%$ sodium pyrophosphate (Bates et al. 1978). Samples were cleaned in boiling nitric acid and rinsed six times with distilled-deionized water via centrifugation. Cleaned samples were dried on a $25 \mathrm{~mm} X$ $25 \mathrm{~mm}$ \#1 coverslip and mounted on a slide with

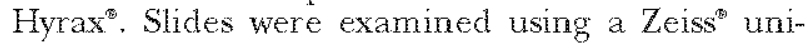
versal microscope at a magnification of $625 \times$. At least 250 diatom valves were counted per slide, which provides a good estimate of the diatom species $\geq 1.5 \%$ of the population (Parsons 1996 ).

The top sample and every tenth sample thereafter were counted from each core. If obvious differences were noted between adjacent samples, every fifth sample was counted. If obvious differences were noted between these adjacent samples, every sample in the interval was counted.

\section{DIATOM DATA ANALYSIS}

A diatom-based salinity index (SI) was formulated using a multiple-variable regression technique comparing diatom species-salinity groupings with the available salinity data. A similar approach was taken by Flower (1986) in his study of $\mathrm{pH}$ changes in lakes. When compared with maximum likelihood and weighted average techniques employed in other studies (see Juggins 1992), this technique is not as complex and probably lacks some needed detail. We believe our simplified approach is adequate to determine if the diatom assemblage reflects salinity changes in the coastal marsh environment.

Salinity classifications were determined from the literature for as many as possible of the counted diatom species $\geq 1.5 \%$ of the population. Many diatom taxonomic texts were used to identify and classify the diatom species encountered in this study (Hustedt 1939, 1955; Voigt 1960; Hendey 1964; Patrick and Reimer 1966, 1975; Cleve-Euler 1968; Foged 1975, 1980, 1986a,b, 1987; Germain 1981; Navarro 1982; Archibald 1983; Caljon 1983; Gasse 1986; Krammer and Lange-Bertalot 1986 , 1988, 199la,b; Prasad et al. 1990; Round et al. 1990; Vos and de Wolf 1998; Mann 1994). Broad salinity classifications were used to standardize the disparate salinity groupings devised by these references, and to acknowledge the dynamic environment typical of the Louisiana coastal marshes. The
TABLE 1. Characteristics of the salinity data used in this study. The sampling stations are listed according to the agency that collected the data (Louisiana Department of Wildlife and Fisheries: LDWF; Department of Health and Hospitals: DHH) and corresponding coring sites (Airplane Lake, APL; Terrebonne marsh site, TSMP; or Fourleague Bay marsh site, FLB). Samples were collected weekly or monthly, although not on a consistent basis (\% missing). Salinity ranges and means are also listed.

\begin{tabular}{lccc}
\hline \multicolumn{1}{c}{ Station } & APL & DHH 107 & DHH 190 \\
Length of record & $1972-1998$ & $1972-1996$ & $1971-1996$ \\
Frequency of sampling & weekly & monthly & monthly \\
\% missing & $58 \%$ & $63 \%$ & $63 \%$ \\
Salinity range $(\% \circ)$ & $2-34$ & $0-25$ & $0-26$ \\
Mean salinity $(\% 0)$ & 20.2 & 9.4 & 4.1 \\
\hline
\end{tabular}

salinity groups used in this study, based on Kolbe (1927) and Round (1981), refer to salinity ranges within which a particular species thrives best, or most commonly occurs: freshwater $(0-5 \%)$, estuarine $(5-20 \%)$, and marine $(>20 \%)$. The percentage of the diatom population classified in each group was summed for each sample.

In several cases a salinity classification could not be assigned to a diatom species because either the species could not be identified or no salinity information was found in the literature. This problem was corrected by dividing the percentage of the diatom population within each salinity group by the percentage that could be classified, thereby standardizing the classifications to one and allowing direct comparisons among the samples. The three salinity classifications could not be used concurrently in the multiple-variable regression due to singularity difficulties caused by the standardization procedure. The SI, therefore, was based on two ratios: the fresh water to estuarine component (FE) and the estuarine to marine component (EM).

\section{SALINITY DATA ANALYSIS}

Salinity data were obtained from the Lovisiana departments of Wildlife and Fisheries (LDWF) and Health and Hospitals (DHH) at Airplane Lake and two other sites within $1 \mathrm{~km}$ of the other two coring sites (FLB and TSMP; Fig. 1). Some characteristics of the salinity data are given in Table 1. We applied a seasonal correction to the data in an attempt to circumvent potential problems due to the highly variable nature of the data and sporadic sampling. The seasonal correction was computed as follows: monthly means for each salinity data set were calculated and then these values were subtracted from the specific measurements taken during the respective month.

An overall mean salinity was computed by averaging the monthly means. This value was added to the difference between the monthly mean and 
TABLE 2. Description and core dating results of the three study sites; the Terrebonne salt marsh pond (TSMP), Airplane Lake (APL), and the Fourleague Bay brackish matsh pond (FLB). The areas were estimated from scaled aerial maps; salinity ranges are from Table 1. Water depths were recorded from field observations; major plant communities were identified in the field. Postextrusion core lengths and \% compaction values are given. See text and refer to Figure 2 for core dating results and discussion.

\begin{tabular}{|c|c|c|c|}
\hline Study site & TSMP & $A F L$ & FLE \\
\hline Surface water area (hectares) & $\mathrm{l}$ & 25 & 2 \\
\hline Salinity $(\%)$ & $0-25$ & $2-34$ & $0-26$ \\
\hline Water depth $(\mathrm{m})$ & $0.5-1$ & $1-2$ & $0-0.5$ \\
\hline Major plant community & Spantina altemifiora & Spartina altermiflora & Spantina patens \\
\hline Confirmed stability (via maps) & since 1932 & since 1955 & since 1955 \\
\hline Date cores were collected & August 18, 1992 & August 26, 1993 & Octoker 17,1994 \\
\hline Postextrusion core length (cm) & 68.7 & 105.7 & 74.3 \\
\hline \% compaction & 3.0 & 4.3 & 8.3 \\
\hline${ }^{137} \mathrm{Cs}$ peak $(\mathrm{cm})$ & 35.5 & 9.5 & 36.5 \\
\hline${ }^{137} \mathrm{Cs}$ sedimentation rate $\left(\mathrm{cm} \mathrm{yr}^{-1}\right)$ & 1.24 & 0.33 & 1.19 \\
\hline 210 $\mathrm{pb}$ sedimentation rate $\left(\mathrm{cm} \mathrm{yr}^{-1}\right)$ & 0.8 & 0.31 & 0.8 \\
\hline Average sedimentation rate $\left(\mathrm{cm} \mathrm{yr}^{-1}\right)$ & 1.0 & 0.32 & 1.0 \\
\hline Time frame represented by each core & $1924-1992$ & $1664-1993$ & $1920-1994$ \\
\hline
\end{tabular}

each specific measurement to return the data to the same range of values as in the raw data. This step was needed to compare the SI with the salinity data directly. Three-year running averages of the seasonally corrected salinity data were used to simulate surface sediment mixing processes.

\section{STATISTICAL ANALYSIS}

Sedimentation rate estimates acquired through core dating allowed us to assign an approximate date to each sample analyzed for diatoms. The years in which salinity data and diatom data matched were used for statistical analysis relying on the assumption that sedimentation rate-derived dates of the diatom data corresponded to the actual dates of the salinity data. A regression analysis (PROG REG procedure of SAS 1988 ) was conducted between the diatom (FE and EM) and salinity data to determine if there was a significant and positive linear relationship between the two datasets. A significant relationship would provide evidence that the diatoms preserved in the sediment preserved a record of past salinity in Louisiana's coastal marshes. The regression model was then applied to the diatom data to formulate a SI for all of the samples analyzed from the three sediment cores; the assumption was that the SI would reflect actual salinity trends. Trends in the data were examined using a model II regression analysis of the SI versus the core dates since both terms have errors associated with their estimates (Sokal and Rohlf 1969). Significant regression results would indicate annual trends in the SI, and therefore, salinity. The SI and 3-yr ruming averaged sam linity data were plotted together versus time (date) for each site to inspect visually how well the SI reflected actual salinity and if date mismatches were evident between the actual dates of the salinity data versus the radioisotope-derived dates of the SI data.

\section{Results \\ Core Dating and STE DESCRIPTIONS}

Table 2 presents general site descriptions, field measurements made during the core collection trips, and core dating results. Two of the sites (TSMP and APL) are surrounded by salt marsh dominated by Spartina alterniflora, while the brackish marsh site (FLB) was a homogeneous marsh of Spartina patens. The three sites ranged in size from a small pond (TSMP) to a larger lake (APL), and also differed in water depth, ranging from very shallow $(0.5 \mathrm{~m}, \mathrm{FLB})$ to rather deep for a marsh water body ( $1-2 \mathrm{~m}$, APL). Postextrusion sediment core lengths ranged from $68.7 \mathrm{~cm}$ to $105.7 \mathrm{~cm}$, with associated levels of compaction of $3 \%$ to $8.3 \%$.

The peaks in ${ }^{137} \mathrm{Cs}$ activity represent the year(s) 1963-1964 (Milan et al. 1995) and occur at a core depth of $9.5 \mathrm{~cm}$ (APL), $35.5 \mathrm{~cm}$ (TSMP), and 36.5 $\mathrm{cm}$ (FLB) (Fig. 2). Note that several data were excluded within the TSMP core for the determination of the $210 \mathrm{~Pb}$ regression line (indicated by the x's; Fig. 2). These data were from the surface mixed layer (the top three samples; Benninger et al. 1979), bioturbation events $(35 \mathrm{~cm}$ and $60 \mathrm{~cm}$; Hejnis et al. 1987), or a peat layer $(69 \mathrm{~cm})$ that contained a large amount of plant material (Parsons 1996), which can enrich surrounding sediments with $210 \mathrm{~Pb}$ (Koide et al. 1972; Olsen et al. 1985). Sedimentation rates ranged from $0.32 \mathrm{~cm}$

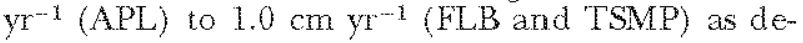
termined by averaging the sedimentation rates estimated by the ${ }^{137 \mathrm{Cs} \text { and }} 210 \mathrm{~Pb}$ techniques. The cores contained a record of $68 \mathrm{yr}$ (TSMP) to a potential of $380 \mathrm{yr}$ (APL). The $380 \mathrm{yr}$ record of the APL core is questionable as this value is based on 

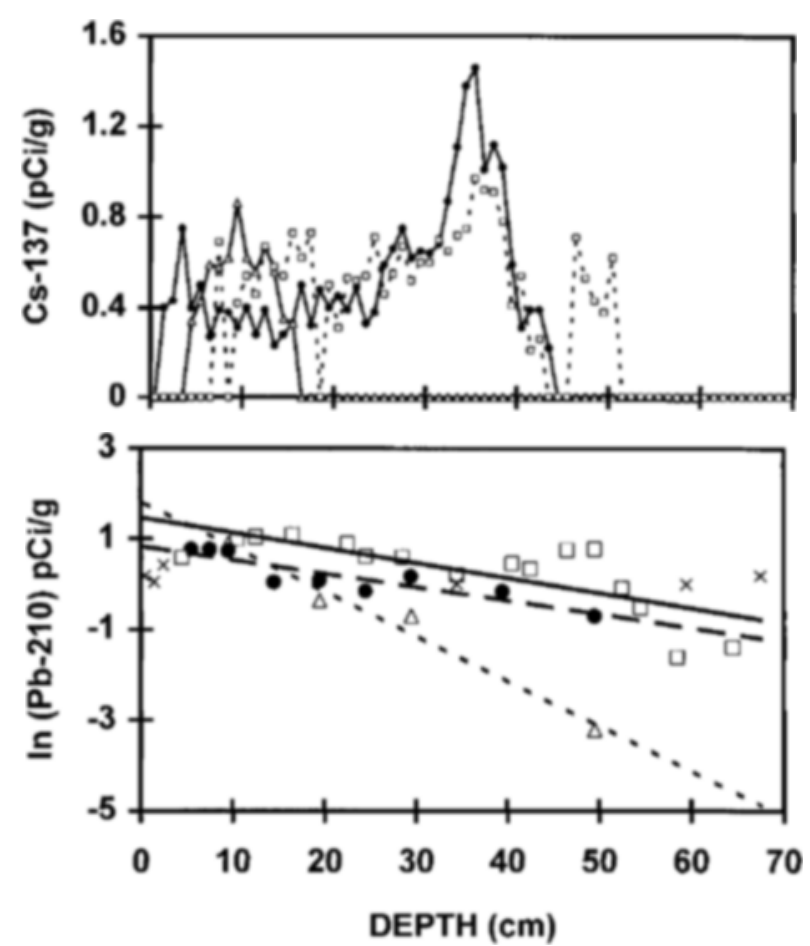

Fig. 2. ${ }^{137} \mathrm{Cs}$ activity and regression of $\ln \left({ }^{210} \mathrm{~Pb}\right)$ activity versus core depth at Airplane Lake (APL-triangles), the Fourleague Bay brackish marsh site (FLB-squares), and the Terrebonne Bay salt marsh pond site (TSMP-black circles). The ln (2iopb) activity regression line equations and $r^{2}$ values are $\mathrm{FLB}$ (solid line) $\ln (y)=-0.0333 x+1.4684\left(r^{2}=0.58\right)$; TSMP (largedashed line) $\ln (y)=-0.0303 x+0.8444\left(r^{2}=0.82\right)$; and APL (small-dashed line) $\ln (y)=-0.0997 x+1.8456\left(r^{2}=0.97\right)$.

the assumption that the whole core has an average sedimentation rate of $0.32 \mathrm{~cm} \mathrm{yr}^{-1}$. The lack of ${ }_{13} 7 \mathrm{Cs}$ activity in the upper $3.5 \mathrm{~cm}$ and $6.5 \mathrm{~cm}$ of the APL and FLB cores, respectively, and the constant ${ }^{210} \mathrm{~Pb}$ activity in the upper $3.5 \mathrm{~cm}$ of the TSMP core demonstrate that sediment mixing appeared to be limited to the upper $4 \mathrm{~cm}$ of sediment in the three cores.

\section{DLATOM ANALISIS}

A total of 89,726 diatom valves representing 205 species from 60 genera were identified and enumerated in 101 samples analyzed from the three sites. Of these 205 species, 125 could be assigned a salinity classification. The 43 most common species ( $\geq 5 \%$ abundance in any sample) are given in Table 3. The proportion of valves counted that could be classified ranged from $90 \%$ from FLB-68 $\mathrm{cm}$ to $100 \%$ from several samples in the APL and TSMP cores. A total of 37 samples were counted from FLB $(1-20,25,30,35,40,45,50,55,60,65-$ $71,74$, and 75$), 37$ from TSMP $(1-10,15,20,25-$ $35,39-49,45,50,55,60,65-69)$, and 27 from APL $(1-10,13,17,20-22,24,26,28,30,40,50,60,70$,
TABLE 3. All diatom species $\geq 5 \%$ relative abundance in at least one sample that could be assigned a salinity classification. The references used to obtain these classifications are indicated by the superscript following each species, which refer to the following works: 1-Foged 1980; 2-Foged 1987; 3-Marshall and Alden 1993; 4-Prasad et al. 1990; 5-Caljon 1983; 6-Vos and deWolf 1993; 7-Foged 1986a; 8-Hustedt 1955; 9-Patrick and Reimer 1966; 10-Hendey 1964; 11 -Carpelan 1978, 12Krammer and Lange-Bertalot 1986,1988, 1991a,b; 13-Round et al. 1990; 14-Mann 1994; and 15-Hustedt 1939. The maximum relative abundance is given for each species (rounded to the nearest percentage), including the core site ( $A$... Airplane Lake; $\mathrm{F}$ - Fourleague Bay; and $\mathrm{T}$ - = Terrebonne Bay) and depth in which the maximum abundance occurred.

\begin{tabular}{|c|c|}
\hline \multicolumn{2}{|l|}{ Marme Spectes } \\
\hline Achanthes brevipes var. intermedia & \\
\hline (Kützing) Cleve ${ }^{1}$ & $7 \%(\mathrm{~F} 66)$ \\
\hline Actinoptychis serarius Ehrenberg ${ }^{2,6,7}$ & $10 \%(\mathrm{~T} 65)$ \\
\hline Amphora temuissina Hustedt ${ }^{3}$ & $6 \%(\mathrm{~T} 41)$ \\
\hline Diploneis didyma (Ehrenberg) Ehr., ${ }^{2,12}$ & $11 \%(\mathrm{~T} 65)$ \\
\hline Diploneis mithiu (Brebisson) Cleve & $5 \%(F 70)$ \\
\hline Ditolum brightorulliz (West) Grunowis & $7 \%(\mathrm{~A} 10)$ \\
\hline Melasira moriliformis (O.F. Muller) Agardh ${ }^{6}$ & $8 \%(\mathrm{~F} 75)$ \\
\hline Novicule yarrensis Grunow & $27 \%(\mathrm{~T} 68)$ \\
\hline Nitzschia compressa (Bailey) Boyer5,12 & $19 \%(\mathrm{T2})$ \\
\hline Nitzschia lanceola Grunow $w^{2,1 \bar{z}}$ & $6 \%(A 5)$ \\
\hline Nitzschia bardumformis Gregoryzi, & $10 \%(\mathrm{~A} 2)$ \\
\hline Pdromeis marina (Ralfs in Pritchard) Mann ${ }^{5,13}$ & $24 \%(\mathrm{~A} 20)$ \\
\hline Thalassiasina eccentrica Ehrenberg.5 & $10 \%(\mathrm{AI})$ \\
\hline Tryblionello grarasulata var. granulatata & \\
\hline & $59 \%(18)$ \\
\hline \multicolumn{2}{|l|}{ Estuarine species } \\
\hline Achwanthes submarina, Hustedt ${ }^{12}$ & $44 \%(\mathrm{~F} 15)$ \\
\hline Amphora copulata Giffen ${ }^{12}$ & $36 \%(\mathrm{~T} 55)$ \\
\hline Bacillaria paradoxe, Gmelin 27.8 & $8 \%(\mathrm{~F} 2)$ \\
\hline Bircmis ambigubs (Cleve) Mann ${ }^{8,10}$ & $8 \%(\mathrm{~T} 69)$ \\
\hline Calaneis westici (W. Smith) Hendey 12 & $11 \%(\mathrm{~A} 24)$ \\
\hline Cyciotella caspía Grunow 3 & $5 \%(A 1)$ \\
\hline Golotella choctowishatcheeana Prasad ${ }^{4}$ & $5 \%(\mathrm{Fl})$ \\
\hline Cyclatella mereghiniana Kützingii & $10 \%(\mathrm{~T} 69)$ \\
\hline Cymbello lancealata (Ehrenberg) Kirchner ${ }^{12}$ & $8 \%(\mathrm{~F} 68)$ \\
\hline Dickicic ulbacea Berkeley ex. Kützing ${ }^{14}$ & $8 \%($ F19) \\
\hline Diploneis funica (Ehrenberg) Cleve & $21 \%(\mathrm{E} 71)$ \\
\hline Diplorieis priella (Schumann) Cleve & $14 \%(F 5)$ \\
\hline Fallacia tenera (Hustedt) Mann ${ }^{12}$ & $9 \%($ A 2$)$ \\
\hline Fragilaria brevistriata Grunow $w_{1,12}$ & $56 \%(\mathrm{~T} 41)$ \\
\hline Gyrosigma peismis (Grunow) Hustedt!.: & $5 \%(\mathrm{~T} 41)$ \\
\hline Luticolo maticica (Kützing) Mann ${ }^{6}$ & $5 \%(570)$ \\
\hline Melosira nummaloides (Dillwyn) Agardh ${ }^{1,8,10}$ & $9 \%($ F 75$)$ \\
\hline Navicula circugrtexa Meister & $8 \%(\mathrm{~T} 1)$ \\
\hline Nawicula consentanea Husted $\mathrm{t}^{15}$ & $8 \%(\mathrm{~T} 1)$ \\
\hline \multicolumn{2}{|l|}{ Navicula salinamem var. minima } \\
\hline (Grunow) Colby 2,8,12 & $10 \%(\mathrm{~F} 7)$ \\
\hline Nitzschia filiformis (W. Smith) Van Heurck, & $13 \%(F 3)$ \\
\hline Rhopalodia acuminata Krammer ${ }^{6,12}$ & $10 \%(\mathrm{~T} 40)$ \\
\hline Tabullaria tabulata (Agardh) Snoeijs $\mathrm{s}^{1,2,6}$ & $6 \%(\mathrm{~T} 39)$ \\
\hline \multicolumn{2}{|l|}{ Freshwater species } \\
\hline Anomoeoneis sphaerothora (Kützing) Pfitzer $1,7,8$ & $7 \%(\mathrm{~F} 66)$ \\
\hline Aulacaseira granulata (Ehrenberg) Simonsen $n^{1,9}$ & $12 \%(\mathrm{~F} 74)$ \\
\hline Cacconeis placentula var. eughopta Ehrenberg $1,5,7$ & $5 \%(\mathrm{~T} 69)$ \\
\hline Fragilaria pinnata. Fhrenberg, & $17 \%(\mathrm{~A} 7)$ \\
\hline
\end{tabular}




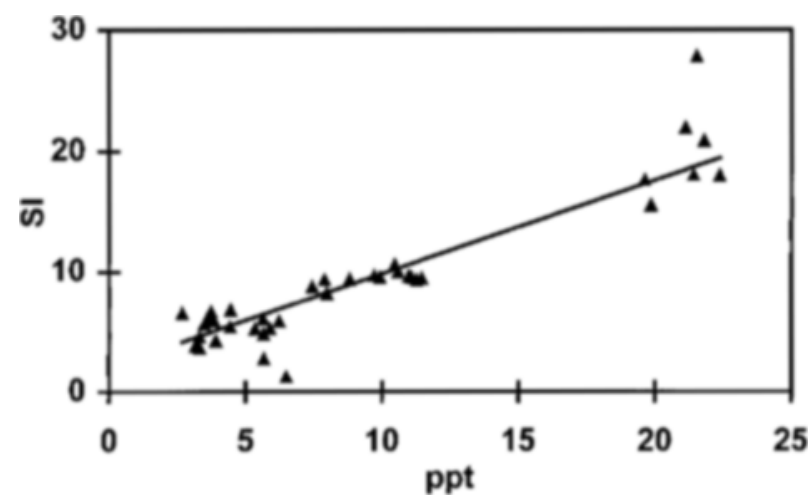

Fig. 3. Regression of the diatom-based salinity index (SI) versus measured salinity from salinity and core data collected at or in the vicinity of Airplane Lake (APL), the Fourleague Bay brackish marsh site (FLB), and the Terrebonne Bay salt marsh pond site (TSMP). The SI was computed as follows, where FE refers to the fresh water to estuarine ratio and EM refers to the estuarine to marine ratio: SI $=36.88(\mathrm{FE})-0.61(\mathrm{EM})+9.03$; $r^{2}=0.86 ; p<0.0001$

$80,90,100$, and 106). Fewer than 250 diatom valves were found in APL core samples below 30 $\mathrm{cm}$ so the statistical analyses were limited to the upper $30 \mathrm{~cm}$ of the core, which represented the time frame 1901 to 1993.

\section{STATISTICAL ANALYSES}

A statistically significant linear regression model $(p<0.0001)$ was formulated using two diatom-salinity components, FE and EM, that predicted the actual salinity values $\left(r^{2}=0.86\right)$, where one unit of SI equaled 0.86 units of salinity (\%o) (Fig. 3). SI values for samples below $30 \mathrm{~cm}$ in the APL core indicate that salinities may have fluctuated over a range of approximately 5-30\% during the past $300 \mathrm{yr}$ (Fig. 4a). This is based on the assumption that the SI reflected an adequately preserved diatom population regardless of the low counts in these samples. In the past century, the salinity index demonstrated that there was an overall significant increase in salinity of 0.10 SI $(0.09 \%) \mathrm{yr}^{-1}$ in the upper $30 \mathrm{~cm}$ of the APL core $(\mathrm{p}=0.0008$; Fig. 4b). The FLB SI displays a significant decrease of $0.11(0.09 \%) \mathrm{yr}^{-1}(\mathrm{p}<0.0001$; Fig. 4c). There is an overall significant increase of $0.015 \mathrm{SI}$ $(0.01 \%) \mathrm{yr}^{-1}$ in the TSMP core $(p=0.009$; Fig. 4d). The bottom sample of the TSMP core was not included in the SI reconstruction because analyses indicated a possible allochthonous origin of this peat layer (Parsons 1996).

\section{Comparison of the SI and Salinity Data}

The SI data display the same range of salinities as the actual salinity data from the three study sites (Fig. 5), but date mismatches are evident (exam-
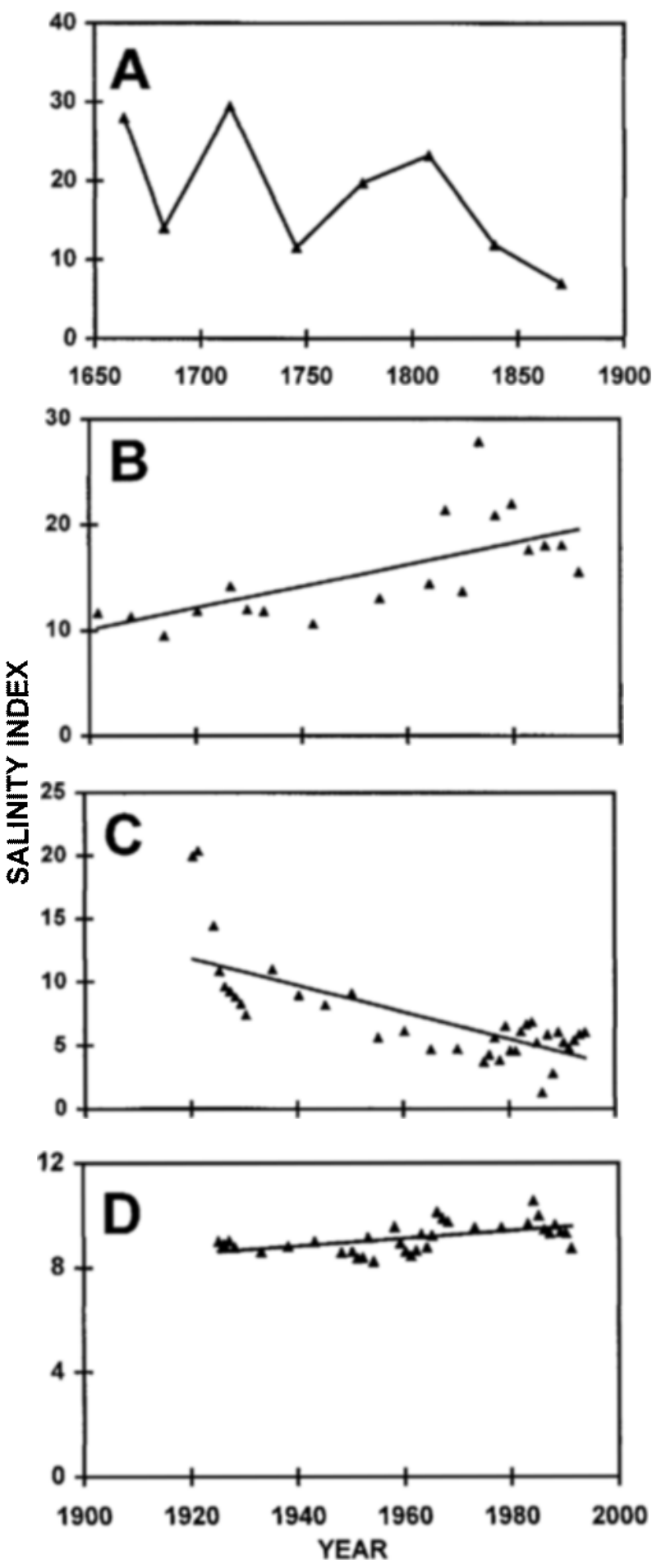

Fig. 4. The diatom-based salinity index (SI) determined salinity profile for the Airplane Lake (A and B), Fourleague Bay (C), and Terrebonne Bay (D) sediment cores. Statistically-significant overall model II trends in the SI are illustrated for Airplane Lake from 1901 to 1993 (SI = 0.103(year) $-185.1 ; r^{2}=$ $0.49 ; p=0.0009$ ); Fourleague Bay (SI $=-0.105$ (year) +214.1 ; $\mathrm{r}^{2}=0.58 ; \mathrm{p}<0.0001$ ) and Terrebonne Bay (SI $=0.012$ (year) $\left.-14.22 ; r^{2}=0.18 ; p=0.009\right)$. 

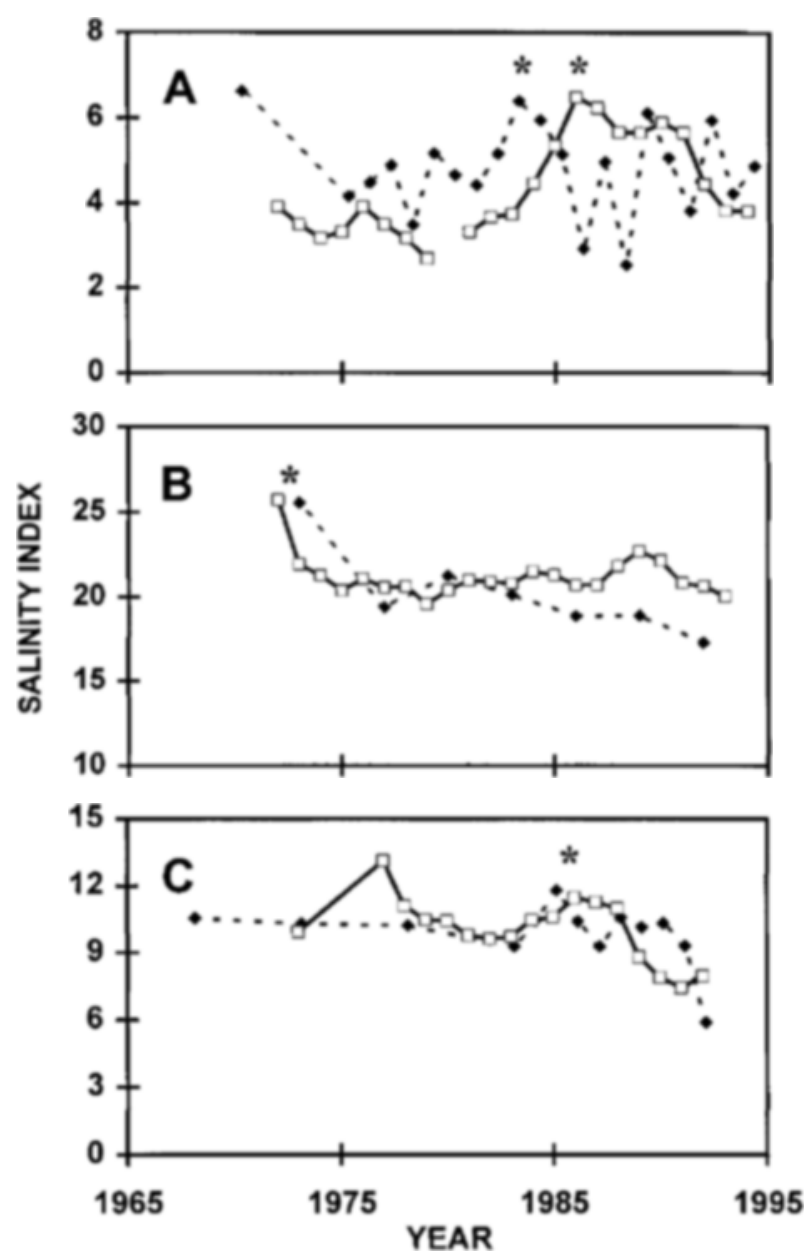

Fig. 5. Direct comparison of the salinity index (black diamonds and dotted lines) and 3-yr running average salinity data (open squares and solid lines) for Fourleague Bay (A), Airplane Lake (B), and Terrebonne Bay (C). The asterisks indicate possible date mismatches between the two datasets.

ples indicated by the asterisks in Fig. 5). The FLB SI appears to be mismatched with the salinity data, possibly due to dating errors (Fig. 5 a). The FLB SI shows more variability than the 3-yr averaged salinity data, suggesting that the salinity data may have been smoothed too much. A decreasing trend in the APL SI is evident (Fig. 5b) but is not corroborated by the actual salinity data collected at Airplane Lake. The TSMP SI matches the salinity data well except for 1986-1992 (Fig. 5c).

\section{Discussion \\ THE SALINITY INDICES}

Diatom remains appear to preserve a record of past salinity in the sediment of the coastal marshes of Louisiana (Fig. 3). The SI reconstructions do not support the hypothesis of significant coastwide salinity increases, but indicate that salinity trends vary regionally and temporally (Fig. 4), confirming earlier salinity studies (Wiseman et al. 1990; Swenson and Swarzenski 1995). The large fluctuations in the SI between the late 1600s and 1900 indicate that salinities may exhibit wide fluctuations on century time scales (Fig. 4a). The SI increase at APL between 1901 and 1993 ( $1 \%$ per decade; Fig. 4b) may be another example of such fluctuations. This increase appears to be driven by a group of high SI values in the 1960 s during a period of low Mississippi River discharge in the 1950s and 1960s (Bratkovich et al. 1994). Century-scale fluctuations in salinity may be driven by climatic variation, as evidenced in fluctuating river discharge (Bratkovich et al. 1994) and possibly precipitation (Laird et al. 1996a,b). There is an apparent decrease in the SI from 1973 to 1998 , but this trend is not supported by the accompanying salinity data (Fig. 5b), which demonstrates that the SI model has flaws (see below). The decreasing salinity indicated in the FLB SI ( $\sim 1 \%$ per decade; Fig. $4 c)$ may be due to the increased discharge of the Atchafalaya River as it began to capture the flow of the Mississippi River (Bratkovich et al. 1994). This hypothesis is confirmed by a statistically significant relationship between the FLB SI and Atchafalaya River discharge $\left(r^{2}=0.365, p<0.0001\right.$, data not shown). While the TSMP SI demonstrates that salinity has increased, the increase is minute $(0.01 \%$ $\mathrm{yr}^{-1}$; Fig. 4d). The lack of a large change could reflect robustness of the SI model at TSMP, or indicate that the salinity regime has changed little at the TSMP site. The latter possibility is interesting in that the Houma Navigational Canal (HNG) is less than $2 \mathrm{~km}$ away from TSMP, and Wang (1988) demonstrated that the HNG may serve as a conduit of higher salinity Gulf waters into the area. The TSMP results may indicate that the areas affected by higher salinities might be very localized $(<2$ $\mathrm{km}$ distance).

\section{ROBUSTNESS OF THE SI MODEI}

While sediment-preserved diatoms can be used to reconstruct salinity profiles in the coastal marshes of Louisiana, the SI reconstruction model can and should be improved. The $r^{z}$ of the regression model $(0.86)$ upon which the SI is based indicates that it does not explain $14 \%$ of the variability. Figure 8 reveals that the SI did not perform well at the high salinity end of the model $(\sim 20 \%)$, and that many data points near the low end were poorly estimated as well. Figure 5 demonstrates that the SI and salinity data did not match up well in some cases. Much of this error could be due to the sporadic nature of the available salinity data, improper salinity classification of some of the diatom species, or errors associated with core dating. 


\section{Gritigue of Salinity Data}

The salinity data used in this study were discrete data, and the sporadic nature of the data collection (Table 1) may have resulted in a poor representation of the salinity regime. This is best exemplified by the observation that the data were collected less than $50 \%$ of the time, and were often collected during the spring (e.g., Airplane Lake; March through May between 1992 and 1998). The data were also collected weekly or monthly, which is typical for Louisiana salinity data (Swenson and Swarzenski 1995). The hydrology of Louisiana's coastal marshes is very dynamic and cyclic salinity variability is influenced by diunal tides (on daily scales), river flow, and precipitation (seasonal to annual scales; Swenson and Swarzenski 1995). An analysis of salinity measurements should account for these cyclic variations, but this is generally not the case.

\section{CRITIQUE OF DHATOM DATA}

The responses of diatoms to salinity can vary widely among species and within a species. There is evidence that a diatom species can display different salinity optima in different water bodies, although tolerance ranges generally overlap (Cumming and Smol 1993; Fritz et al. 1993; Wilson et al. 1994, 1996). Some diatom species may have very large tolerances (i.e, euryhaline) and therefore will not be useful to reconstruct estuarine salinity (Juggins 1992). Wilderman (1987) believed this was especially true at salinities of $8-16 \%$, for which no reliable indicators may exist. The potential robustness seen in the TSMP SI at a salinity of $\sim 10 \%$ may reflect such tolerances. Many species exhibit salinity optima. Because these responses are not linear, linear models (as was used for this study) might not be the best analytical approach (Juggins 1992). A particular diatom species response to salinity changes may differ based on the duration, frequency, and magnitude of change (Carpelan 1978; Admiraal and Peletier 1980). It is important, therefore, to know how salinity changes (frequency, etc) and how a species will react to these salinity changes.

\section{CRITQUe OF CORE DATING RESULTS}

The core dating techniques employed in this study result in average estimates of sedimentation rates. The ${ }^{137} \mathrm{C}$ s estimates are an average rate for the period between 1963-1964 and the time the core was collected, while the $210 \mathrm{~Pb}$ estimates are an average based on the slope of a regression for the sediment core samples analyzed. As sedimentation rates vary year to year (especially during hurricane events, Parsons 1998), the use of an overall average sedimentation rate can cause a poor estimation of core-derived dates. There were differences between estimates of sedimentation rate as determined by ${ }^{197} \mathrm{Cs}$ and ${ }^{210 \mathrm{~Pb}}$ for FLB (39\% difference; 1.19 versus $0.8 \mathrm{~cm} \mathrm{yr}^{-1}$; Table 2) and TSMP (35\%;

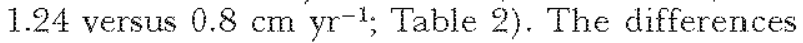
in the two estimates indicate changing sedimentation rates (greater since 1963-1964), compaction, or oxidation (Turner unpublished data).

The possible errors and flaws in the core dating estimates may have caused date mismatches between some core samples and the salinity data. Date mismatches (e.g., FLB, Fig. 5a) could increase variability in the SI regression, resulting in decreased $r^{2}$. The high $r^{2}(0.86 ;$ Fig. 3), however, demonstrates the core dates and actual salinity dates matched up reasonably well, considering the errors that can be expected.

\section{COMparison WTth OTHER Diatom-Based Salinity INDICES}

The SI model developed in this study performed similarly to salinity indices applied in other sediment core studies. Fritz (1990) developed a diatom-based salinity index to reconstruct a salinity history of Devils Lake, North Dakota, U.S., and compared the model to available salinity records. While their model estimated salinities fairly well below $10 \%$, it did not consistently differentiate salinities between $10 \%$ and $25 \%$. Laird et al. (1996a) demonstrated that diatom-inferred salinity changes in a sediment core from Moon Lake, North Dakota, matched up well with available climatological data (precipitation minus evapotranspiration) after the $1940 \mathrm{~s}$, but mismatches were apparent in the mid 1970 s. Wilson et al. (1996) reported their recent refinement of a salinity inference model for a region in British Columbia, Canada, in which the $r^{2}$ was improved to 0.87 . We believe, therefore, that our salinity model is an adequate attempt at reconstructing salinity in coastal marsh environments.

\section{Conclusions}

The SI holds great potential as a tool to further study salinity changes in Louisiana and other coastal marshes impacted by hydrologic modifications. This study has demonstrated that there is no evidence for a coastwide increase in salinity. Fluctuations in salinity may be related to increased riverine discharge (FLB) and may vary widely over centuries (APL). This demonstrates the importance of riverine freshwater inputs as a controlling factor of salinity, and that long-term studies are needed to determine natural variability. While the SI has revealed much about historical salinity regimes in coastal Louisiana, some of the results are questionable, and may reflect flaws in this study and the 
model design. An apparent decrease in the SI of the APL core was not corroborated by salinity data. The TSMP SI had less variability than the salinity data, indicating that the model may be too robust at a salinity of $\sim 10 \%$. The next logical step is to address these tlaws and refine the SI. Field data on the salinity ranges and optima for the diatoms living in the marshes of coastal Louisiana should be collected so that the SI can more accurately predict actual salinity values (i.e., improve the $x^{2}$ and slope so that both approach one). Application of the refined SI to more sites with longer sediment records would provide a wealth of information on salinity changes. It also potentially would provide improved baseline data from which anthropogenic impacts and marsh deterioration can be assessed, and proper remedial measures taken.

\section{ACKNOWLEDGMENTS}

We thark D. Reed for helpful comments; M. Sullivan for instruction in diatom taxonomy; P. LaRock for the use of his lab oratory space and microscope; J. Lee, D. Justic, E. Swenson, G. Peterson, and A. Bass for help collecting sediment cores; B. Cole, R. Robichaux, and L. Smith for their aid splitting the cores; and the Louisiana departments of Wildlife and Fisheries and Health and Hospitals for salinity data. This research was funded by Louisiana Sea Grant R/M PE-59 awarded to $R$. E Turner, N. N. Rabalais, and Q. Dortch, a State of Louisiana Board of Regents Graduate Fellowship Brogram, the Louisiana Sea Grant College Program, a part of the National Oceanic and Atmospheric Administration's National Sea Grant College program, and a Louisiana Universities Marine Consortium Postdoctoral Fellowship to M. L. Parsons.

\section{LITERATURE CITED}

ADMIRAat, W. AND H. PELETIER. 1980. Distribution of diatom species on an estuarine mud flat and experimental analysis of the selective effect of stress. Joumal of Experimertal Marine Biology ard Ecology 46:157-175.

AMSFOKER, M. C. AND C. D. MCINTIRE. 1978. Distribution of intertidal diatoms associated with sediments in Yaquina estuary, Oregon. Jourrat of Phycology 14:387-395.

ARCHIBALD, R. E. M. 1983. The diatoms of the Sundays and Greatfish rivers in the Eastern Cape Province of South Africa. Bibitatheca Diatomologica 1:1-362, 33 plates.

Alexander, C. E., M. A. Broutman, And D. W. Fetdo. 1986. Inventory of the Nation's Wetlands. National Oceanic and Atmospheric Administration, Strategic Assessment Branch, Rockville, Maryland.

BAIRD, D. AND J. J. HEXMANS. 1996. Assessment of ecosystem changes in response to freshwater inflow of the Kromme Rivex estuary, St. Francis Bay, South Africa: A network analysis approach. Water South Africa 22:307-318.

Bates, C. D., P. COXON, AND P. L. GrBBARD. 1978. A new method for the preparation of clay-rich sediment samples for palynological investigation. New Phytologist 81:459-463.

BATTARBEE, R. W. AND M. J. KNEEN. 1982. The use of electronically counted microspheres in absolute diatom analysis. Limnology and Ocearography 27:184-188.

BATTAREEE, R. W. 1986. Diatom analysis, p. 527-570. Ih B. E. Berglund (ed.), Handbook of Holocene Palaeoecology and Palaeohydrology. John Wiley \& Sons Ltd., Chichester, United Kingdom.

BaUmann, R. H. AND R. E. TuRNer. 1990. Directimpacts of outer continental shelf activities on wetland loss in the central Gulf of Mexico. Ervironmental Geology and Woter Resaurces 15:189198.

BENNINger, L. K., R. C. Allek, J. K. COChRAN, AND K. K. TUREKXAN. 1979. Effects of biological sediment mixing on the 2:1 $\mathrm{Pb}$ chronology and trace metal distribution in a Long Island Sound sediment core. Earth F'lanetary Science Letters 43 : $241-259$

BRAtKonch, A., S. P. DinNex, ANo D. A. Goolsex. 1994. Variability and prediction of freshwater and nitrate fluxes for the Louisiana-Texas shelf: Mississippi and Atchafalaya river source functions. Estwaries 17:766-778.

CAHOON, D. R. AND D. J. REED. 1995. The relationship between marsh surface topography, hydroperiod, and soil accretion in a deteriorating Louisiana salt marsh. Joumal of Cocstal Research $11: 357-369$.

CALjON, A. G. 1983. Brackish-water phytoplankton of the Flemish lowland, p. 1-272. In H. J. Dumont (ed.), Developments in Hydrobiology 18. Dr. W. Junk Publishers, The Hague.

CARPELAN, L. H. 1978. Evolutionary euryhalinity of diatoms in changing environments. Nova Hedvisigia 29:489-526.

CHABRECK, R. H. AND G. LNSCOMBE. 1982. Changes in vegeta tion types in Lonisiana coastal marshes over a ten-year period. Proceedings of the Lomisiana Academy of Sciences 45:98-102.

Cieve, P. T. 1899. Postglaciala bildningarnas klassifikation pả grund av deras fossila diatomacéer. Sveriges Geologisko. Uridersoekririg 180:59-61.

Cleve-Euler, A. 1968. Die diatomeen von Schweden und Finn land. Verlag von J. Cramer, Germany.

COOK, L. L. AND S. A. WHEPFLE. 1982. The distribution of edaphic diatoms along environmental gradients of a Louisiana salt warsh. Journal of Phycalogy 18:64-71.

COOPER, S. R. 1995. Chesapeake Bay watershed historical land use: Impact on water quality and diatom communities. Ecological Applications 57703-723.

Costanza, R. AND S. C. FARber. 1985. The Economic Value of Wetlands in Louisiana. Final Report to the Coastal Management Section, Louisiana Department of Natural Resources, Baton Rouge, Louisiana.

CUmmono, B. F. AND J. P. Sror. 1993. Development of diatombased salinity models for paleoclimatic research from lakes in British Columbia (Canada). Hydrobiologia 269/270:179-196.

CUtShald, N. H., I. L. LaRSEN, AND C. R. OLSEN. 1983. Direct analysis of $210 \mathrm{~Pb}$ in sediment samples: Self-absorption. Nacleor Instruments and. Methods 206:309-312.

DENYS, L. AND C. VERERUGGEN. 1989. A case of drowning-The end of subatlantic peat growth and related paleoenvironmental changes in the lower Scheldt Basin (Belgium) based on diatom and pollen analysis. Review of Palaeobotany and Polynology $59: 7-36$.

DUDGEON, D. 1995. River regulation in southern China: Ecological implications, conservation, and environmental management. Resonirces Maragemert 11:35-54.

EspinosA, M. A. 1994. Diatom paleoecology of the Mar Chiquita lagoon delta, Argentina. Joumal of Paleolimrology 10:17-23.

FLower, R. J. 1986. The relationship between surface sediment diatom assemblages and pH in 33 Galloway lakes: Some regression models for reconstructing $\mathrm{pH}$ and their application to sediment cores. Hydrobialogia 143:93-103.

FOGED, N. 1975. Some littoral diatoms from the coast of Tanzaxia. Bibliotheca Phycologic 16:1-127, 31 plates.

FOGED, N. 1980. Diatoms in Öland, Sweden. Bibliotheca Phocologia 49:1-193, 18 plates.

FoGED, N. 1986a. Diatoms in Gambia. Bibliotheca Diatomolagica $12(a): 1-152,25$ plates.

FoGED, N. 1986b. Diatoms in the Volo Bay. Bibilotheca Diatomalogica $12(\mathrm{~b}): 1-63,13$ plates.

FOGED, N. 1987. Diatoms from Vitu Levu, Fiji Islands. Bibliotheca Diatomalogica 14:1-195, 33 plates. 
FRTE, S. C. 1990. Twentieth-century salinity and water-level fluctuations in Devils Lake, North Dakota. Limnology ard. Ocear. agraphy 35:1771-1781.

FrTtZ, S. C., S. JugGNS, AND R. W. BATTARBEE. 1993. Diatom assemblages and ionic characterization of lakes of the northern Great Plains, North America: A tool for reconstructing past salinity and climate fluctuations. Caradian Joumal of Fish eries and Aquatic Scrences 50:1844-1856.

FUlJER, D. A., J. G. GOSSEIINK, ]. BARRAs, AND C. E. SASSER. 1995. Status and trends in vegetation and habitat modifications, $p$ 25-76. In D. J. Reed (ed.), Status and Historical Trends of Hydrologic Modification, Reduction in Sediment Availability, and Habitat Loss/Modification in the Barataria and Terrebonne Estuarine System. BTNEP Publication Number 20, Barataria-Terrebonne National Estuary Program, Thibodaux, Louisiana.

GaGliano, 5. 1994. An Environmental-Economic Blueprint for Restoring the Louisiana Coastal Zone: The State Plan. Gow ernor's Office of Coastal Activities and the Wetland Conservation and Restoration Task Force, Baton Rouge, Louisiana.

GAsse, F. 1986. East African diatoms. Bibliotheca Diatomologica 11: $1-202,19$ plates

GERMAEN, H. 1981. Flore des diatomées. Diatomophycées. Eaux douces et saumâtres du Massif Arrooricain et des contrées voisines d'Europe occidentale, Boubee, Paris.

GLENN, E. P., C. LEE, R. FELGER, AND S. ZENGEL. 1996. Effects of water management on the wetlands of the Colorado River delta, Mexico. Comservation Biology 10:1175-1186.

GOOD, R. E., N. F. GOOD, AND B. R. FRasco. 1982. A review of primary production and decomposition dynamics of the below ground marsh component, p. 139-157. In V. S. Kennedy (ed.), Estuarine Comparisons, Academic Press, New York.

HEIJNIS, H., G. W. BERGER, AND D. EISMA. 1987. Accumulation rates of estuarine sediment in the Dollard Area: Comparison of $\mathrm{Pb}-210$ and pollen influx wethods. Netherlands Joumal of See Research 21:295-301.

HENDEX, N. I. 1964. An introductory account of the smaller algae of British coastal waters; Part $\bar{V}$ : Bacillariophyceae (Diatorns). Ministry of Agriculture, Fisheries, and Food. Fishery Investigations Series IV. Otto Koeltz Science Publishers, Koenigstein, West Germany.

HUSTEDT, F. 1939. Die diatomennflora des Küstengebietes der Nordsee vom Dollart bis zür Elbemundung. Á̉handlungen des naturwissenschafer vereins in Bremen 31:572-677.

HustedT, F. 1955. Marine Littoral Diatoms of Beaufort, North Carolina. Duke University Press, Durham, North Carolina.

JuGGINs, 5. 1992. Diatoms in the Thames Estuaxy, England: Ecology, paleoecology, and salinity transfer function. Bibliothoca Diatomolagica $25: 1-216$.

KolBe, R. W. 1927. Zur Ökologie, Morphologie und Systematik der Brackwasser-Diatomeen. Pflorzenforscharg 7:1-146.

KOIDE, M., A. SOUTAR, AND E. D. GOLDBERG. 1972. Marine geochronology with ${ }^{210} \mathrm{~Pb}$. Earth Planetary Science Letters 14:442446.

KRAMMER, K. AND H. LANGERERTALOT. 1986. Bacillariophyceae (Band 2/1), Vol. 1, Naviculaceae. Is B. Pascher, H. Ettl, J. Gerloff, H. Heynig, and D. Mollenhauer (eds.), SüPwasserflora von Mitteleuropa. Gustav Fischex Verlag Jena, Germany.

KRAMNER, K. AND H. LANGE-BERTALOT, 1988. BacillariophyceaC (Band 2/2), Vol. 2, Bacillariaceae, Epithemiaceae, Surirella ceae. In B. Pascher, H. Ettl, J. Gerloff, H. Heynig, and D. Mollenhauer (eds.), SüBwasserflora von Mitteleuropa. Gustav Fischer Verlag Jena, Germany.

KRAMMER, K. AND H. LANGEBERTCOT. 1991a. Bacillariophyceae (Band 2/3), Vol. 3, Centrales, Fragilariaceae, Eunotiaceae. In B. Pascher, H. Ettl, J. Gerloff, H. Heynig, and D. Mollenhauer (eds.), SüBwasserflora von Mitteleuropa. Gustav Fischer Vexlag Jena, Germany.
KRAMMER, K. AND H. LANGE-Bertalot. 1991b. Bacillariophyceae (Band 2/4), Vol. 4, Achnantheceae, Kritische Ergänzungen zu Novicula (Lineolatae) und Gomphomena. In B. Pascher, $H$. Ettl, J. Gerloff, H. Heynig, and D. Mollenhauer (eds.), SüBwasserflora von Mitteleuropa. Gustav Fischer Verlag Jena, Germany.

LAIRD, K. R., S. C. FRTTZ, E. C. GRTMM, AND P. G. MUELIER. 1996a. Century-scale paleoclimatic reconstruction from Moon Lake, a closed-basin lake in the northern Great Plains. Limnology and Ocearography 41:800-902.

LAIRD, K. R., S. C. FRTTZ, K. A. MAASCE. ANU B. F. CUMMENG. 1996b. Greater drought intensity and frequency before AD1200 in the Northern Great Plains, USA. Nature 384:552554

LART, K. R., S. C. FRTIZ, AND B. F. CUMMTNG. 1998. A diatombased reconstruction of drought intensity, duration, and frequency from Moon Lake, North Dakota: A sub-decadal record of the last 2300 years. Jonrmal of Paleolimnology 19:161-179.

MADUEN, C. J., J. W. DAY, JR., AND J. M. RANDALt. 1988. Freshwater and marine coupling in estuaries of the Mississippi River deltaic plain. Limmalogy and Oceanogrophy 33:982-1004.

MANN, D. G. 1994. Auxospore formation, reproductive plasticity, and cell structure in Navicula whace, and the resurrection of the genus Dickieia. (Bacillariophyta). Europear Joumal of Fhycology $29: 141-157$.

Marseial, H. G. AND R. W. Aldeñ. 1993. A comprarison of phytoplankton assemblages in the Chesapeake and Delaware estuaries (USA), with emphasis on diatoms. Hydrobiologia 269/ $270: 251-261$.

MClNTIRE, C. D. AND W. S. OVERTON. 1971. Distributional patterns in assemblages of attached diatoms from Yaquina estuaxy, Oregon. Ecolagy 52:758-777.

MCKEE, K. L. AND I. A. MENDELssofin. 1989. Response of a fieshwater plant community to increased salinity and increased wa ter level. Aquatic Botary 34:301-316.

MEADE, R. H. AND R. S. PARKER. 1984. Sediments in rivers of the United States. National Watex Supply Suxmmary. United States Geological Survey Water Suppip Paper 2275.

MIIAN, C. S., E. M. SWENSON, R. E. TURNER, AND ]. M. LEE. 1995. Assessment of the ${ }^{137} \mathrm{Cs}$ method for estimating sediment accumulation rates: Louisiana salt marshes. Jormal of Coostal $R c$ search 11:296-307

Moore, W. W. AND C. D. MCINTIRE. 1977. Spatial and seasonal distribution of littoral diatoms in Yaquina Estuary, Oregon (USA). Botanica Morrina 20:99-109.

NAVARRO, J. N. 1982. Marine diatoms associated with mangrove prop roots in the Indian River, Florida, U. S. A. Bibliatheco Phicologica 61:1-151, 37 plates.

OLSEN, C. R., I. L. LARSEN, P. D. LOWERX, N. H. CUTSHALX, I. F. TODD, G. T. F. WONG, AND W. H. CASEY 1985. Atmospheric fluxes and marsh-soil inventories of ${ }^{7} \mathrm{Be}$ and ${ }^{210 \mathrm{~Pb}}$. Jommal of Geophysical Research 90(D6):10,487-10,495

Orson, R. A. 1996. Some applications of paleoecology to the management of tidal marshes. Estraries 19:238-246.

PARSONS, M. L. 1996. Paleoindicators of changing water conditions in Louisiana estuaries. Ph.D. Dissertation, Department of Oceanography and Coastal Sciences, Louisiana State University, Baton Rouge, Louisiana.

PARSONS, M. L. 1998. Salt marsh sedimentary record of the landfall of Hurricane Andrew on the Louisiana coast: Diatoms and other paleoindicators. Joumal of Coastal Research 14:939-950.

PATRICK, R. AND C. W. RETMER. 1966. The Diatoms of the United States (exclusive of Alaska and Hawaii). I: Fragilariaceae, Eu notiaceae, Achnanthaeae, Naviculaceae. Monographs of The Academy of Natural Sciences of Philadelphia, no. 13. Philadelphia.

PAIRTCK, R. AND C. W. REIMER. 1975. The Diatoms of the United States (exclusive of Alaska and Hawaii). II: Part I. Mono 
graphs of The Academy of Natural Sciences of Philadelphia, no. 13. Philadelphia.

Pennington, W., R. S. Cambrax, and E. H. Fisher. 1973. Obsexvations on lake sediments using fallout ${ }^{137} \mathrm{Cs}$ as a tracer. Nature 242:324-326

PRASAd, A. K. S. K., J. A. NiENow, ANo R. J. Lrwngston. 1990. The genus Cyclotella (Bacillariophyta) in Choctawhatchee Bay, Florida, with special reference to $C$. striata and $C$. choctawhatcheeara sp. nov. Phycologia 29:418-436.

RÄSÄNEN, M. 1986. Recent sedimentation in a freshwater reservoir in SW-Finland: The diatomological and chemical evidence of sediments on the development of the water body. Hydrobiologia 143:361-369.

RÄSÄNEN, M. ANO K. TOLONEN. 1983. Changes in diatom flora deposited annually during the freshening of the impounded sea-bay of Gennarbywiken in southern Finland. Hydrobiologia $103: 147-152$

REED, D. J. 1989. Patterns of sediment deposition in subsiding coastal salt marshes, Terrebonne Bay, Louisiana: The role of winter storrus. Estraties 12:222-227

REED, D. J. 1990. The impact of sealevel rise on coastal salt marshes. Progress in Physical Geographin 14:24-40.

REED, D. J. 1995. The response of coastal marshes to sea-level rise: Survival or submergence? Earth Science Processes and Landforms $20: 39-48$

Round, F. E. 1981. The Ecology of the Algae. Cambridge University Press, Cambridge, England.

ROUND, F. E., R. M. CRAWFORD, AND D. G. MANN. 1990. The Diatoms. Cambridge University Press, Cambridge, England.

SAS'. 1988. SAS\% /STAT User's Guide, Release 6.03 Edition. SAS Institute Inc., Cary, North Carolina.

SCHiELSKE, C. L. 1991. Historical nutrient enrichment of Lake Ontario: Paleolimnological evidence. Caradiar joumal of Fish eries and. Aquatic Sciences 48:1529-1538.

SOKAL, R. R. AND F. J. ROHLF. 1969. Biometry. W. H. Freeman and Company, San Francisco, California.

Stanley, D. J. ANd G. A. GoOdfruend. 1997. Recent subsidence of the Suez Canal. Natnre 388:335-336.

SWENSON, E. M. AND R. E. TURNER. 1987. Spoil banks: effects on a coastal marsh water level regime. Estuarine. Caastal and Shellf Scierce 24:599-609.

SWENSON, E. M. AND C. M. SWARZENSKR. 1995. Water levels and salinity in the Barataria-Terrebonne estuarine system, p. 129 201. Iw D. J. Reed (ed.), Status and Historical Trends of Hydrologic Modification, Reduction in Sediment Availability, and Habitat Loss/Modification in the Barataria and Terrebonne Estuarine System. BTNEP Publication Number 20, Barataria-Terrebonne National Estuary Program, Thibodaux, Louisiana.

Thon, R. M. 1997. System development matrix for adaptive management of coastal ecosystem restoration projects. Ecological Engireerirgy 8:219-232.
TURNER, R. E. 1987. Relationships between canal and levee density and coastal land loss in Louisiana. United States Fish and Wildife Service Biological Report 85(14). Washington, D.C.

TURNER, R. E. 1997. Wetland loss in the northern Gulf of Mexico: Multiple working hypotheses. Estuaries 20:1-13.

TURNER, R. E. AND J. G. GOSSEI NNK. 1975. A note on standing crop of Spartiva alberrifitara in Texas and Florida. Combritutions iro Marine Science 19:13-18.

Underwood, G. C., J. Philldes, and K. SAUnders. 1998. Distribution of estuarine benthic diatom species along salinity and nutrient gradients. European Jouryal of phycology 33:173-183.

VAN StCKLE, V. R. B. B. BARRETT, L. I. GULICK, AND T. B. Ford. 1976. Barataria Basin: Salinity Changes and Oyster Distribution. Center for Wetland Resources, Louisiana State University, Baton Rouge. Sea Grant Publication LSU-T 76-002.

VoIGT, M. 1960. A new diatom genus from east Asia. Joumal Rovil Microscopic Society 79:95-96.

VOS, P. C. AND H. DE WOLF. 1993. Reconstruction of sedimentary environments in Holocene coastal deposits of the southwest Netherlands; the Poortvliet boring, a case study of paleoenvironmental diatom research. Hydrobiologia 270:297-306.

WANG, F. C. 1988. Dynamics of saltwater intrusion in coastal channels. Jourral of Geophysical Research 93(C6):6937-6946.

WANG, Y. 1996. Plain coast changes: Human impacts and riversea system control-Examples from China, p. 172-179. In E Duursma (ed.), Conference on Coastal Change, Bordomer95. Workshop Report IOC 105 supplement, United Nations Educational, Scientific and Cultural Organization, Paris.

WrLDERMAN, C. C. 1987. Patterns of distribution of diatom assemblages along environmental gradients in the Severn River Estuary, Chesapeake Bay, Maryland. Joumal of Phycology 23: 209-217.

Wruson, S. E., B. F. Cummang, ANo J. P. SRol. 1994. Diatomsalinity relationships in 111 lakes from the interior plateau of British Columbia, Canada: the development of diatombased models for paleosalinity reconstructions. Journal of Paleolim nology 12:197-221.

Wilson, S. E., B. F. Cummang, ano J. P. Smol. 1996. Assessing the reliability of salinity inference models from diatom assemblages: an examination of a 219-lake data set from western North America. Canadian Joumal of Fisheries and Aquatic Sciences 53:1580-1594.

WrSEMAN, JR., W. J., E. M. SWENSON, AND J. POWER. 1990. Salinity trends in Louisiana estuaries. Estrafies 13:265-271.

WOLANSER, E., N. N. HUAN, L. T. DAO, N. H. NEAN, ANO N. N. ThuY. 1996. Fine-sediment dynamics in the Mekong River Estuary, Vietnam. Estudnire, Coastal and Shelf Science 43:565-582

ZEULER, J. B., T. WINFIEID, AND P. WuLIAAMS. 1980. Salt marsh productivity with natural and altered tidal circulation. Oecolo gia $44: 236-240$

Received for cors sideration, March 18,1998 Accepted for publication, Jupe 10, 1999 